\title{
Metformin Prevents Peritoneal Dissemination via Immune-suppressive Cells in the Tumor Microenvironment
}

\author{
TAKANORI HIRAYAMA ${ }^{1}$, YASUHIRO NAGATA ${ }^{1,2}$, MIKAKO NISHIDA $^{3}$, \\ MITSUTOSHI MATSUO ${ }^{4}$, SHINICHIRO KOBAYASHI ${ }^{1}$, AKIRA YONEDA $^{1}$, \\ KENGO KANETAKA ${ }^{1}$, HEIICHIRO UDONO ${ }^{3}$ and SUSUMU EGUCHI ${ }^{1}$ \\ ${ }^{1}$ Department of Surgery, Nagasaki University Graduate School of Biomedical Sciences, Nagasaki, Japan; \\ ${ }^{2}$ Center for Comprehensive Community Care Education, \\ Nagasaki University Graduate School of Biomedical Sciences, Nagasaki, Japan; \\ ${ }^{3}$ Department of Immunology, Okayama University Graduate School of Medicine, \\ Dentistry and Pharmaceutical Sciences, Okayama, Japan; \\ ${ }^{4}$ Department of Surgery, Nagasaki Memorial Hospital, Nagasaki, Japan
}

\begin{abstract}
Background/Aim: Metformin, a drug for type 2 diabetes, also exerts anticancer effects. This study addressed the immunological effects of metformin on peritoneal dissemination. Materials and Methods: We developed a mouse model of peritoneal dissemination via intraperitoneal injection of RLmale1, an X-ray-induced leukemia cell line, into BALB/c mice. Cell-surface markers, cytokine production, and myeloidderived suppressor cells (MDSCs) were examined in cells from spleen and peritoneal lavage fluid. Results: Metformin-treated mice exhibited suppressed intraperitoneal tumor growth and extended survival, and these effects were lost in mice with severe combined immunodeficiency. MDSCs induction was inhibited in metformin-treated mice. Although MDSC mobilization into the peritoneal cavity was correlated with suppression of interferon$\gamma$ production by tumor-infiltrating lymphocytes, the T-helper 1 ability of these lymphocytes was preserved in metformin-treated mice. Conclusion: Our findings demonstrate the action of metformin on both intraperitoneal tumors and immunesuppressive cells and might contribute to the development of immunotherapy against peritoneal dissemination.
\end{abstract}

Peritoneal dissemination is often a fatal outcome of gastrointestinal malignancies. Despite advances in combination treatment modalities involving surgery, radiotherapy, and

Correspondence to: Yasuhiro Nagata, Center for Comprehensive Community Care Education, Nagasaki University Graduate School of Biomedical Sciences, 1-12-4 Sakamoto, Nagasaki 852-8523, Japan. Tel: +81 958197046, Fax: +81 958197048, e-mail: ynagata1961@nagasaki-u.ac.jp

Key Words: Myeloid derived suppressor cell, tumor microenvironment, peritoneal dissemination, metformin. chemotherapy for this intractable state, the survival rate remains low. Intraperitoneal immunotherapy represents a novel strategy for managing peritoneal dissemination. Cytoreductive surgery and hyperthermic intraperitoneal chemotherapy have remained the gold standard for treating peritoneal dissemination over the past three decades; however, despite optimal treatment, recurrence rates remain high and long-term survival is poor (1). The remarkable progress in cancer immunology has raised expectations for the development of immunotherapy against peritoneal dissemination. We have demonstrated that peritoneal dissemination is promoted by immune exhaustion in the peritoneal cavity (2). It is now accepted that tumors generate an immune-suppressive microenvironment that facilitates evasion and inhibition of immune responses through a number of distinct factors, including the recruitment of immunesuppressive cell populations, such as regulatory T-cells (Tregs) and the secretion of immune-suppressive cytokines $(3,4)$. Management of functional T-cell exhaustion at the tumor site is currently the extensive focus of cancer immunotherapy along with efforts to neutralize Tregs and myeloid-derived suppressor cells (MDSCs) (5).

Metformin, a drug used against type 2 diabetes that suppresses gluconeogenesis in the liver via adenosine monophosphate-activated protein kinase, has been reported to exert unexpected clinical anticancer effects $(6,7)$. A number of studies have been conducted to identify the underlying mechanism of metformin action, and most have examined its direct effect on tumor cells (8-10). A cardinal study using a mouse model showed that the anticancer effect of metformin was mediated by immunological pathways. Specifically, metformin prevented the immune exhaustion of $\mathrm{CD}^{+}$tumor-infiltrating lymphocytes (TILs) (5). The antitumor activity of metformin is attributable to reduced immune-suppressive activity of MDSCs and Tregs (11). 


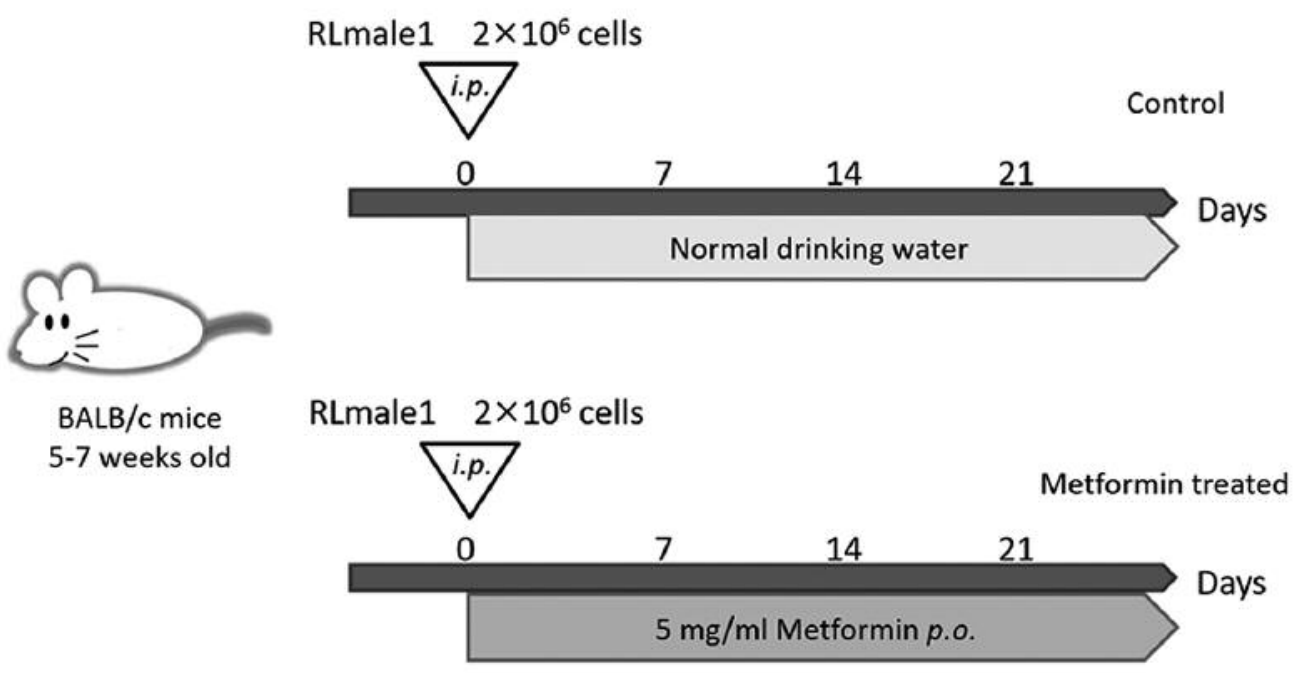

Figure 1. Schema of experiment. RLmale1 cells $\left(2 \times 10^{6}\right.$ cells in $200 \mu l, 1 \times 10^{7}$ cells $/$ ml $)$ were injected into mice intraperitoneally (i.p.). From day 0 , non-diabetic mice were given water containing metformin dissolved at a concentration of $5 \mathrm{mg} / \mathrm{ml}$ and were denoted as the metformin-treated group.

In this study, we addressed the effect of metformin on peritoneal dissemination and investigated the mechanism of evading immune exhaustion involved therein.

\section{Materials and Methods}

Mice. Six- to eight-week-old male BALB/c mice were obtained from Charles River Laboratories (Tsukuba, Japan). The mice were kept in a specific-pathogen-free environment under humane conditions. Mice with severe combined immunodeficiency (SCID) on the BALB/c background were obtained from the Department of Immunology, Okayama University. The animal experiments were reviewed and approved by the Biomedical Research Center of Nagasaki University (approval number: 14061155), and were performed according to the recommendations for the proper care and use of laboratory animals and The Law (No. 105) (12) and Notification (No. 6) (13) of the Japanese Government and the Guide for the Care and Use of Laboratory Animals by the National Institutes for Health (14).

Cell culture. The BALB/c mouse X-ray-induced leukemia cell line, RLmale1, was obtained from the RIKEN Bio Resource Center (Ibaraki, Japan) $(15,16)$. The cells were maintained in Roswell Park Memorial Institute 1640 medium supplemented with $10 \%$ fetal bovine serum in a humidified atmosphere containing $5 \%$ $\mathrm{CO}_{2}$ at $37^{\circ} \mathrm{C}$. To investigate the direct effect of metformin, RLmale1 cells were maintained in vitro with different concentrations of metformin [control (0), 10, 20, 50, 100, 500, $1,000,5,000,10,000 \mu \mathrm{M}]$ for 72 hours and cell viability was measured by the trypan blue dye-exclusion method (17). The assay was replicated eight times.

Tumor growth assay. RLmale1 cells $\left(2 \times 10^{6}\right.$ cells in $200 \mu 1,1 \times 10^{7}$ cells $/ \mathrm{ml})$ were injected intraperitoneally into experimental mice $(\mathrm{n}=8$ for each groups) according to a previously reported protocol (18). Metformin (Wako, Osaka, Japan) was orally administered at a dose of $5 \mathrm{mg} / \mathrm{ml}$ in drinking water following a previous protocol (5). As shown in Figure 1, mice were divided into two groups; metformin-treated and control. On days 7, 14 and 21, mice were sacrificed, and tumor growth was evaluated ( $\mathrm{n}=8$ for each groups). Cells from spleen and peritoneal lavage fluid were collected for flow cytometric analysis. Visible tumors on the peritoneal wall and the mesenteries were collected and tumor weight from each mouse was measured during sacrifice $(19,20)$.

Flow cytometric analysis. Cells from spleen and peritoneal lavage fluid were stained with the following monoclonal antibodies to: CD3e (peridinin chlorophyll-cyanine 5.5 conjugated); CD4, natural killer (NK) 1.1 CD44, lymphocyte antigen 6 complex locus G6D (Ly6G), interferon- $\gamma$ (IFN- $\gamma)$ and interleukin 10 (IL-10) (phycoerythrin-conjugated); CD8a, CD25, CD62L and CD11b [allophycocyanin (APC) conjugated]; lymphocyte antigen 6 complex, locus C1 (Ly6C, fluorescein isothiocyanate-conjugated); and CD127 (phycoerythrin-cy7phycoerythrin-cyanine 7 conjugated). Gr1 was defined as positivity for Ly6G and Ly6C. The antibodies were purchased from Becton Dickinson and Co. (Tokyo, Japan). An intracellular cytokine staining assay was performed using the BD Pharmingen $^{\mathrm{TM}}$ Leukocyte Activation Cocktail; stimulating with phorbol 12-myristate 13 acetate, ionomycin, and brefeldin A. Cells were analyzed using a FACS Canto ${ }^{\mathrm{TM}}$ II cytometer with FACS Diva software (Becton Dickinson and Co.).

Statistical analysis. All data are expressed as scatter plots with a bar indicating the median. The data were examined statistically using the Welch $t$-test. Differences between group was considered statistically significant at $p<0.05$. Statistical analyses were performed using StatMate IV software for Windows (ATMS, Tokyo, Japan). Scatter plots were prepared using GraphPad Prism version 6.00 for Mac (GraphPad Software, San Diego, CA, USA). The survival probability was calculated by the Kaplan-Meier method, and statistical differences were evaluated using the logrank test. 

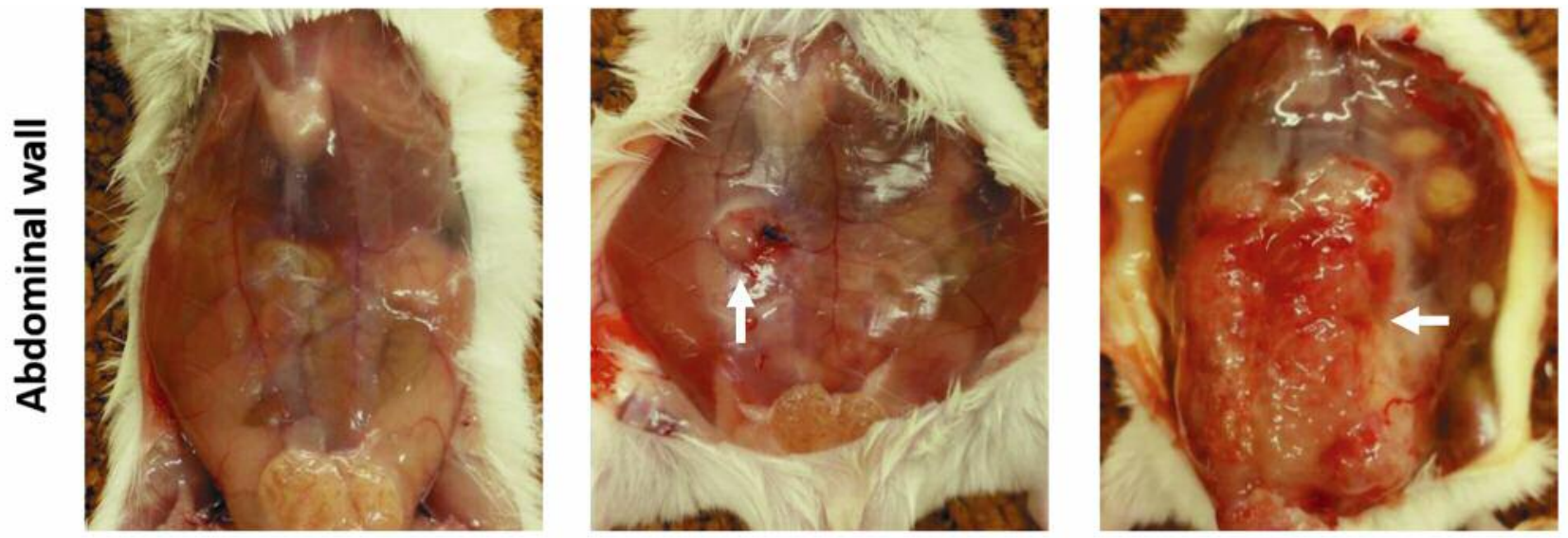

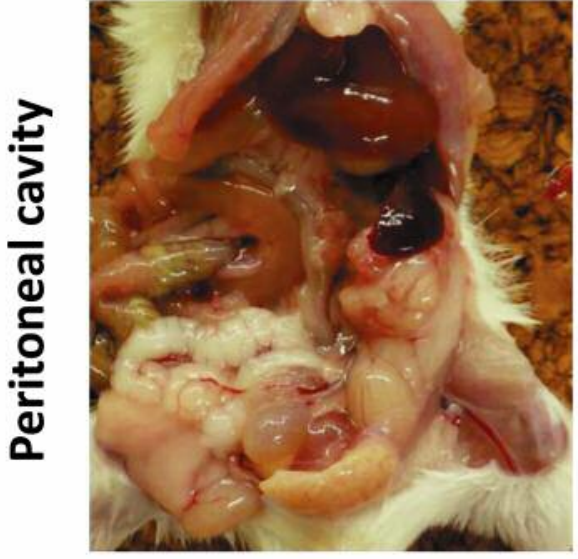

7

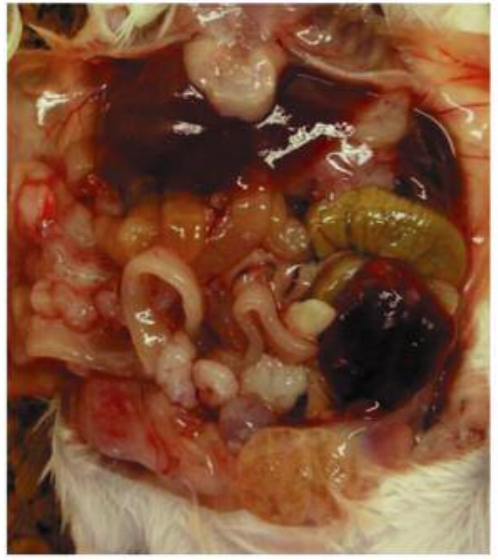

14

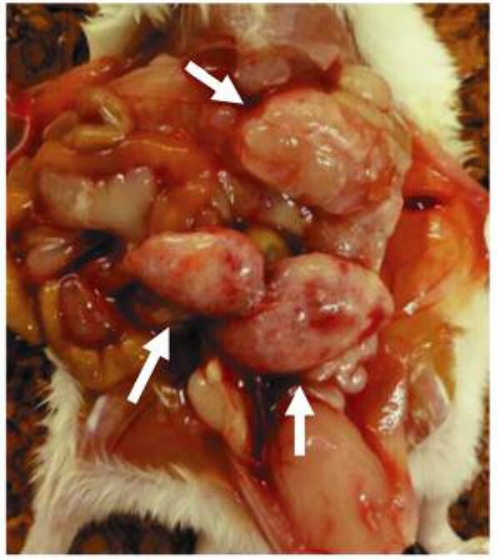

21

\section{Days after tumor injection}

Figure 2. Establishment of a mouse model of intraperitoneal tumor dissemination. The abdominal wall (upper panel) and peritoneal cavity (lower panel) after intraperitoneal injection of RLmale1 cells into BALB/c mice. Minimal ascites was observed on day 7. On day 14, ascites and abdominal wall tumors were detected. On day 21, the volume of ascites had increased, abdominal wall tumors had grown, and intraperitoneal tumor dissemination was apparent. Arrows indicate abdominal wall/intraperitoneal tumors.

\section{Results}

Intraperitoneal tumorigenesis of RLmale1 cells was suppressed by metformin. RLmale1 cells were intraperitoneally injected into two mice groups and tumor growth was evaluated. On day 14 , abdominal wall tumors and mesenteric nodules had formed, and ascites was present (Figure 2). Visible tumors on the peritoneal wall and mesenteries were removed, and the weight of tumors from each mouse was measured. There was no significant difference in tumor weight between the metformintreated and control groups on days 7 and 14. On day 21, the median tumor weight in the metformin-treated mice $(0.338 \mathrm{~g})$ was significantly lower than that in the control mice (6.892 g; Figure 3).
Prolonged survival of metformin-treated mice was mediated by $T$-/B-cells. By day $27,75 \%$ of control mouse had died and all had died by day 49 , whereas most of the metformintreated mice survived over 50 days without mesenteric dissemination (Figure 4A). In an independent experiment shown in Figure 4B, the effect of metformin on survival was lost in SCID mice. The extended survival of metformintreated mice thus demonstrated the necessity for T-/B-cells in mesenteric dissemination.

Direct effect of metformin on the proliferation of RLmale1 cells in vitro. In order to investigate whether metformin affects tumor cells directly, RLmale1 cells were cultured in the presence of metformin at different concentrations (Figure 


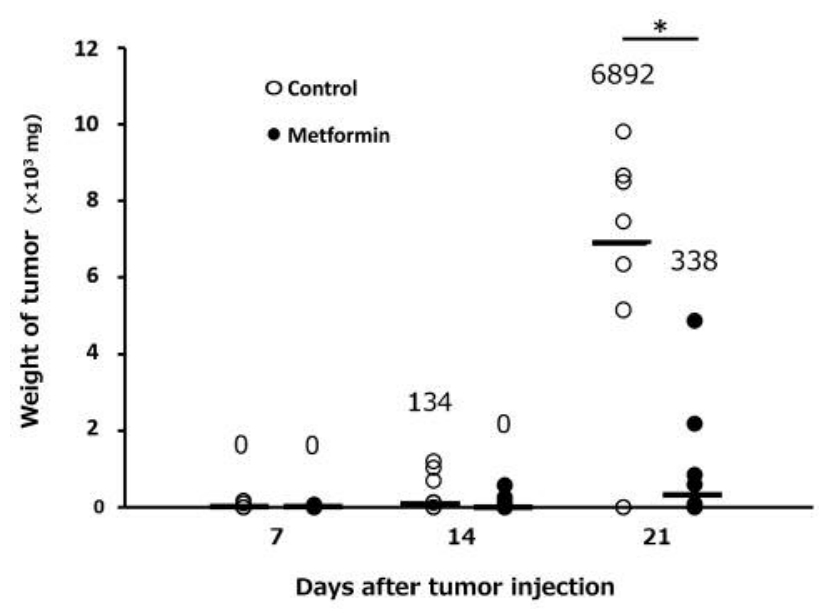

Figure 3. The weight of intraperitoneal tumors. BALB/c mice were injected RLmale1 cells intraperitoneally and treated with normal drinking water or with drinking water containing dissolved metformin $(5 \mathrm{mg} / \mathrm{ml})$ as described in the Materials and Methods section. Mice from each group were sacrificed and examined on day 7,14, and 21, respectively ( $n=8$ per group). Horizontal bars indicate the median tumor weight. The tumor weight of the metformin-treated group was significantly lower than that of the control group. *Significantly different at $p<0.01$.

5). At a metformin concentration of $100 \mu \mathrm{M}$ or higher, proliferation of RLmale1 cells was inhibited in a dosedependent manner. In contrast contrary, below $50 \mu \mathrm{M}$, which corresponds to the clinical dose, metformin did not significantly suppress tumor cell proliferation.

Induction of MDSCs was suppressed in metformin-treated mice. In order to investigate immunological parameters, cells collected from the spleen and peritoneal lavage fluid were analyzed by flow cytometry. As reported previously, it possible to distinguish lymphocytes (TILs) from RLmale1 cells based on their size (Figure 6) (5). All murine MDSCs expressed the plasma membrane markers Gr1 and CD11b, and the granulocyte marker Gr1, including the isoforms Ly6C and Ly6G. In this study, MDSCs were determined to be $\mathrm{CD} 11 \mathrm{~b}^{+} \mathrm{Gr} 1^{+}$cells presenting either $\mathrm{Ly}_{6 \mathrm{C}}{ }^{-} \mathrm{Ly} 6 \mathrm{G}^{+}$or Ly6 ${ }^{\text {high }}{ }^{2 y} 6 \mathrm{G}^{\text {low/- }}$ phenotype (Figure 7) (21).

The subsets of analyzed cells are summarized in Tables I and II. There were no significant differences between the control and metformin-treated mice in the following subsets: $\mathrm{CD}^{+}$and $\mathrm{CD}^{+}{ }^{+} \mathrm{T}$-cells (and their ratio), effector memory $\mathrm{T}$ cells (sorted as $\mathrm{CD} 3 \mathrm{e}^{+} \mathrm{CD} 44^{+} \mathrm{CD} 62 \mathrm{~L}^{-}$), and natural killer cells (sorted as $\mathrm{NK} 1.1^{+}$) on days 7, 14, and 21. For factors of immune suppression, although Tregs, defined as $\mathrm{CD} 3 \mathrm{e}^{+} \mathrm{CD} 4{ }^{+} \mathrm{CD} 25^{+} \mathrm{CD} 127^{\text {low }}$, were increased in tumorbearing mice; there was no significant difference between the control and metformin-treated mice except for MDSCs. Induction of $\mathrm{CD}_{11} \mathrm{~b}^{+} \mathrm{Ly} 6 \mathrm{G}^{+} / \mathrm{Ly} 6 \mathrm{C}^{\text {high }}$ MDSCs was suppressed
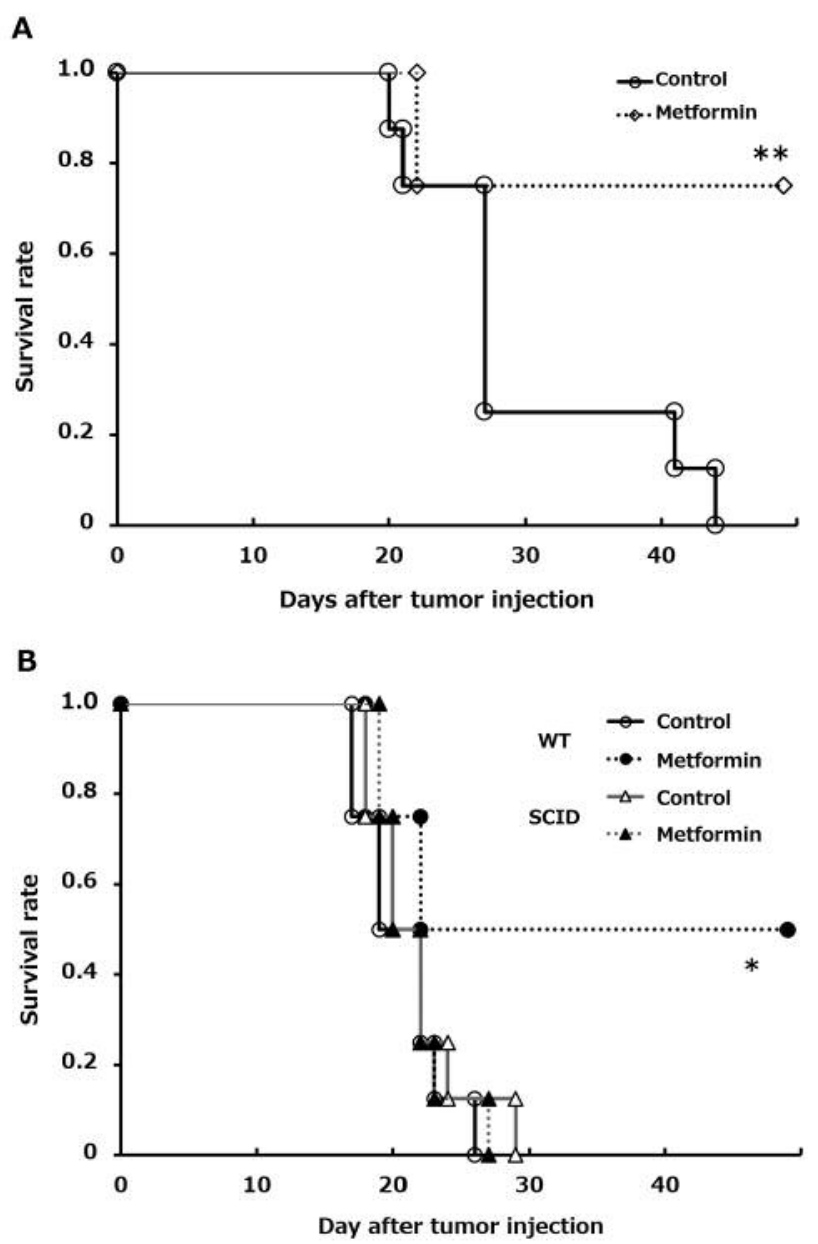

Figure 4. A: Survival curves of tumor-bearing BALB/c mice injected intraperitoneally with RLmale1 cells ( $n=8$ per group) and treated with normal drinking water or with drinking water containing dissolved metformin $(5 \mathrm{mg} / \mathrm{ml})$. Survival of metformin-treated mice was prolonged. $* *$ Hazard ratio $=5.49,95 \%$ confidence interval $=1.67-26.9$; $p<0.01$. B: Survival curves of tumor-bearing wild-type (WT) and severe combined immunodeficiency mice injected intraperitoneally with RLmale1 cells ( $n=8$ per group) and treated with normal drinking water or with drinking water containing dissolved metformin $(5 \mathrm{mg} / \mathrm{ml})$. Wildtype mice without metformin treatment and all SCID mice died by day 29 after injection, whereas half of the wild-type mice treated with metformin were still alive. ${ }^{*}$ Significantly different at $p<0.05$.

in metformin-treated mice, and this was significantly observed in the peritoneal cavity (Table II, Figure 8).

Cytokine production in the state of immune exhaustion. Cytokine production from T-cells in the spleen and peritoneal lavage fluid after stimulation with PMA, ionomycin, and brefeldin A was evaluated by intracellular cytokine staining. IFN- $\gamma$ production by TILs was up-regulated only in metformin-treated mice (Figure 9). 


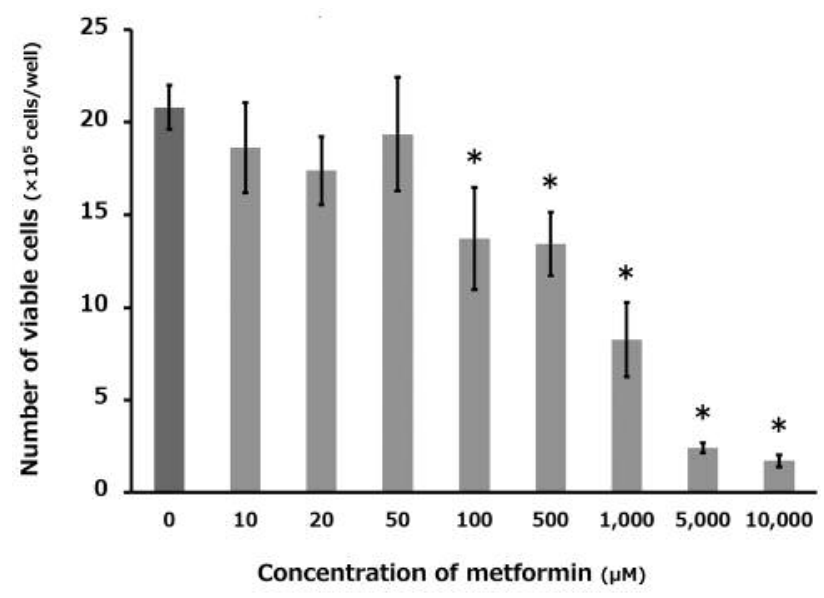

Figure 5. In vitro assay of RLmale1 cells treated with metformin. RLmale 1 cells $\left(1 \times 10^{5}\right)$ were cultured in the presence of metformin at the indicated concentrations for $72 \mathrm{~h}$. Cell viability was determined by trypan blue exclusion. Below $50 \mu \mathrm{M}$, which corresponds to the clinical dose, metformin did not suppress tumor cell proliferation; cell proliferation was suppressed above $50 \mu \mathrm{M}$, compared with the untreated cells $(* p<0.001)$. Data are the mean \pm standard deviation of eight replicates for each group.

\section{Discussion}

In this study, a mouse model of peritoneal dissemination was established following oral administration of metformin. The key findings of the current study were as follows. In mice treated with metformin, (i) tumor growth was suppressed in the presence of T/B cells; (ii) MDSC induction was significantly suppressed in the peritoneal cavity; and (iii) IFN- $\gamma$ production from TILs was up-regulated in the peritoneal lavage fluid. Our findings indicate that in addition to the inhibitory effect of metformin on cancer cells, immune-suppressive cells are critical in understanding the anticancer mechanisms of metformin.

The mouse model of peritoneal dissemination was established by intraperitoneal injection of RLmale1 cells (16, 22). Although most of the experimental mice developed intraperitoneal tumors with ascites by day 21 , the mice treated with metformin showed minimal changes in shape. Observation of the peritoneal cavity after sacrifice clearly revealed the difference between control and metformintreated mice. Metformin has been suggested to directly inhibit the proliferation and invasion of tumor cells (23). However, the plasma concentration of metformin in our setting was expected to be significantly less $(<20 \mu \mathrm{M})$ than that obtained using clinical doses. Thus, metformin might exert an indirect effect on tumor growth (24). Most studies on the antitumor activities of metformin have focused on its cell-autonomous effects on cancer cells, but its potential effects on immune cells within the tumor microenvironment have remained unexplored (25). As extension of survival seen with metformin treatment was lost in SCID mice, we examined the tumor-infiltrating immune cells in the peritoneal cavity. There was no significant difference between the control and metformin-treated mice with respect to the population of major immunocompetent cells except for MDSCs. While the induction of MDSCs was inhibited in metformin-treated mice, IFN- $\gamma$ production from TILs was up-regulated without Treg mobilization. As the effect was more evident in the peritoneal cavity than in the spleen, it is possible that metformin prevented T-cell exhaustion in the tumor microenvironment.

MDSCs have been identified in the bone marrow, liver, blood, spleen, and tumors of tumor-bearing mice based on the expression of surface markers and their ability to prevent Tcell activation. All murine MDSCs express the plasma membrane markers Gr1 and CD11b. Differential expression of these molecules distinguishes monocytic MDSCs from polymorphonuclear MDSCs. Monocytic MDSCs are identified

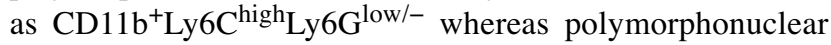
ones are identified as $\mathrm{CD} 11 \mathrm{~b}^{+} \mathrm{Ly}_{6 \mathrm{C}^{-}} \mathrm{Ly}_{6 \mathrm{G}^{+}}(21)$; these two subsets exhibit different modes of immune suppression. Polymorphonuclear MDSCs utilize reactive oxygen species and the enzyme arginase 1, whereas mononuclear MDSCs use nitric oxide synthase 2 and reactive oxygen species (26). These phenotypes are applicable to tumor-infiltrating MDSCs, as well as MDSCs residing in the spleen and blood of tumorbearing mice. Tumor-infiltrating MDSCs are more suppressive compared to blood or splenic MDSCs on a per-cell basis (21, 27-30). In our model, although induction of polymorphonuclear MDSCs was inhibited in the spleen of metformintreated mice, mononuclear MDSCs were also inhibited in the peritoneal cavity.

The mechanisms of peritoneal dissemination have been examined and act as possible foundations for its potential treatment. However, the precise mechanism of peritoneal dissemination is still unclear. Through cytokine production, antigen presentation and phagocytic function, mesothelial cells act as regulators of the complex interaction between the peritoneum and the immune system (31). Metformin has recently received renewed attention due to its preventive effect on organ fibrosis and cancer metastasis by inhibiting epithelial-to-mesenchymal transition. Metformin ameliorates the phenotypic transition of peritoneal mesothelial cells and peritoneal fibrosis by modulating oxidative stress (32). In previous study on peritoneal dissemination, Treg accumulation was observed at the tumor site in patients with gastric cancer (33). However, high levels of Tregs among tumor-infiltrating $\mathrm{CD}^{+}{ }^{+} \mathrm{T}$-cells are not always associated with poor prognosis. Instead, an increase in the proportion of MDSCs has been shown to be an independent adverse prognostic factor in gastric cancer (34). 

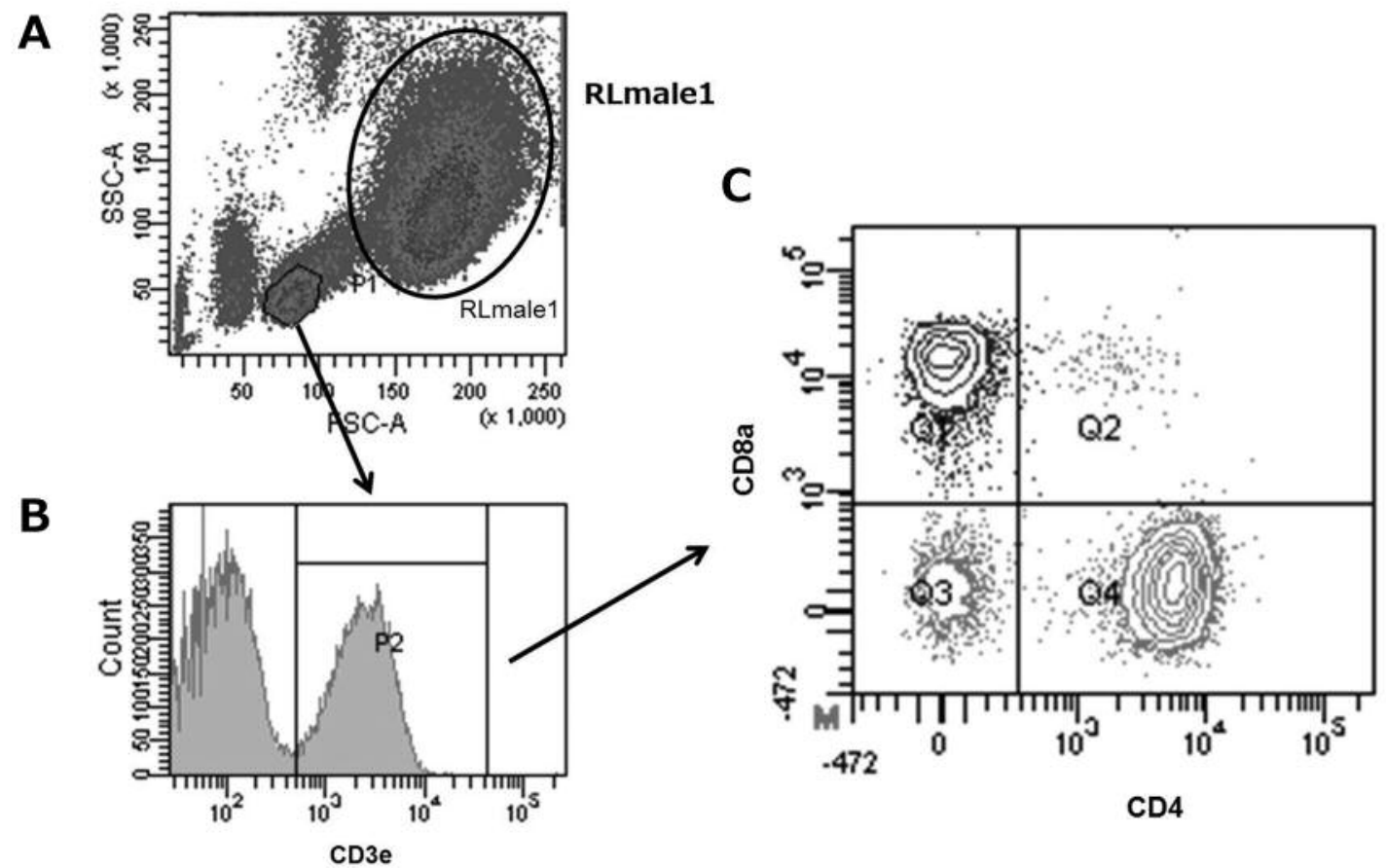

Figure 6. Analysis of lymphocytes in peritoneal lavage fluid of tumor-injected mouse by flow cytometry. A: Lymphocytes were distinguished from tumor cells in the dimension with the forward scatter area (FSC-A) and side scatter area (SSC-A). B:CD3e ${ }^{+}$cells in the gated area were considered T-cells. C: Gated cells were co-stained with CD4 and CD8a, representing T-cells.
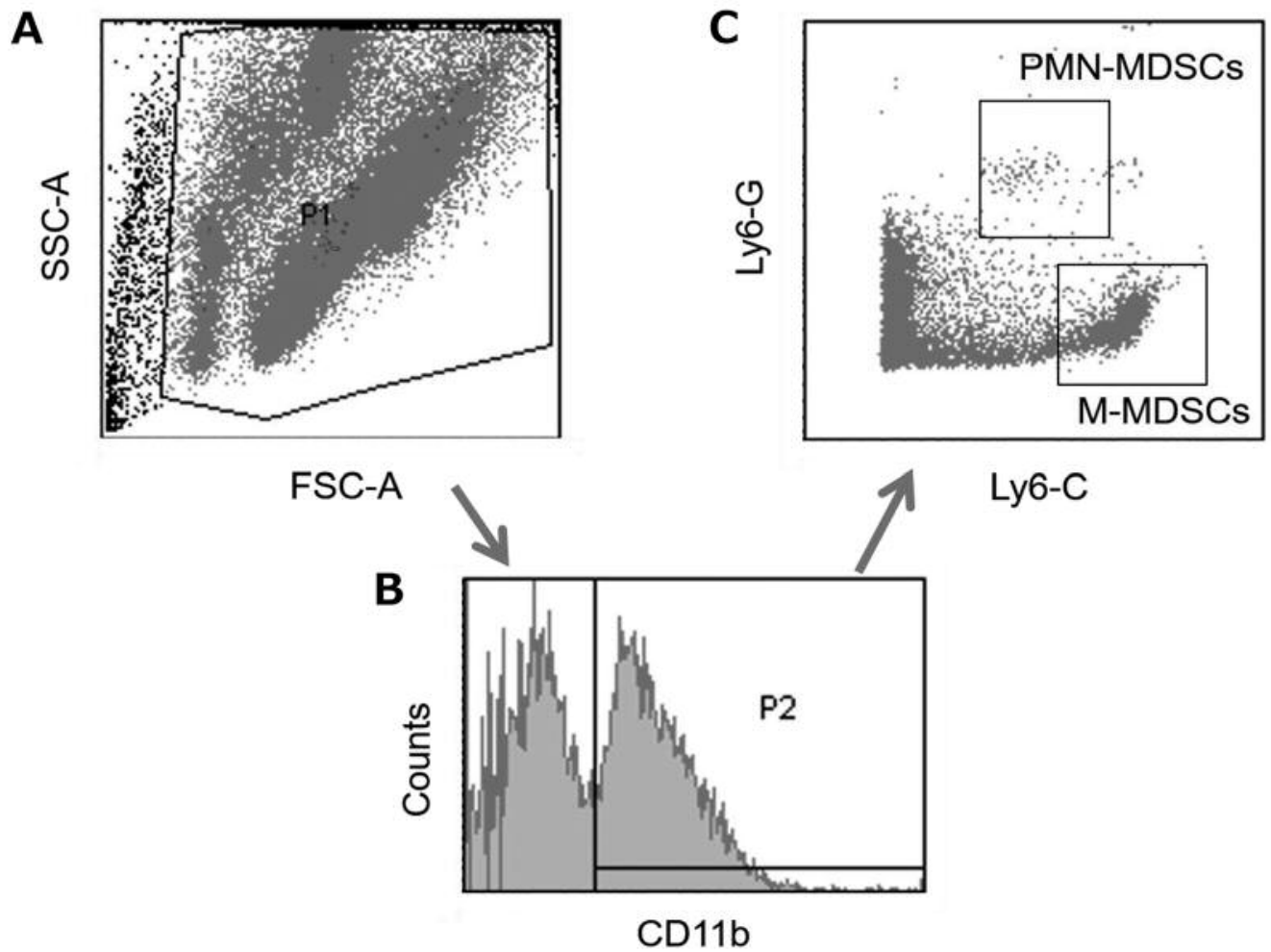

Figure 7. Flow cytometry gating strategy for myeloid-derived suppressor cells (MDSCs). A: CD11 ${ }^{+}$cells were gated from the spleen or peritoneal lavage fluid of tumor-injected mice. B, C: Cells were stained with CD11b, Ly6G, and Ly6C simultaneously. MDSCs were identified as $C D 11 b^{+} L y 6 G^{+} / L y 6 C^{\text {high }}$. $C D 11 b^{+}$Ly6G $G^{+}$represents polymorphonuclear MDSCs (PMN-MDSCs), and CD11b ${ }^{+}$Ly6Chigh represents monocytic MDSCs (M-MDSCs). 
Table I. Subsets of spleen cells under the tumor-bearing state.

\begin{tabular}{|c|c|c|c|c|c|c|c|c|c|}
\hline & \multicolumn{3}{|c|}{ Day 7} & \multicolumn{3}{|c|}{ Day 14} & \multicolumn{3}{|c|}{ Day 21} \\
\hline & \multicolumn{3}{|c|}{ Metformin } & \multicolumn{3}{|c|}{ Metformin } & \multicolumn{3}{|c|}{ Metformin } \\
\hline & - & + & $p$-Value & - & + & $p$-Value & - & + & $p$-Value \\
\hline CD8/CD4 (ratio) & 0.25 & 0.25 & 0.908 & 0.29 & 0.28 & 0.956 & 0.27 & 0.26 & 0.482 \\
\hline $\mathrm{CD} 3 \mathrm{e}^{-\mathrm{NK}} 1.1^{+}(\%)$ & 0.29 & 0.45 & 0.255 & 0.82 & 0.56 & 0.186 & 0.82 & 0.53 & 0.275 \\
\hline $\mathrm{CD} 3 \mathrm{e}^{+} \mathrm{NK} 1.1^{+} \mathrm{CD} 8 \mathrm{a}^{+}(\%)$ & 0.03 & 0.03 & 0.926 & 0.07 & 0.05 & 0.600 & 0.08 & 0.09 & 0.275 \\
\hline $\mathrm{CD} 3 \mathrm{e}^{+} \mathrm{CD} 44^{\mathrm{lo}} \mathrm{CD} 62 \mathrm{~L}^{\text {high }} \mathrm{CD} 4(\%)$ & 1.76 & 1.87 & 0.497 & 2.40 & 2.27 & 0.363 & 1.40 & 1.32 & 0.346 \\
\hline $\mathrm{CD} \mathrm{e}^{+} \mathrm{CD} 44^{\mathrm{lo}} \mathrm{CD} 62 \mathrm{~L}^{\text {high }} \mathrm{CD} 8(\%)$ & 2.42 & 5.78 & 0.283 & 6.71 & 5.11 & 0.099 & 6.21 & 2.21 & 0.118 \\
\hline $\mathrm{CD} \mathrm{e}^{+} \mathrm{CD} 44^{\text {high }} \mathrm{CD} 62 \mathrm{~L}^{\text {high }} \mathrm{CD} 4$ (\%) & 30.61 & 34.86 & 0.254 & 41.62 & 53.69 & 0.051 & 35.03 & 29.23 & 0.050 \\
\hline $\mathrm{CD} \mathrm{e}^{+} \mathrm{CD} 44^{\text {high }} \mathrm{CD} 62 \mathrm{~L}^{\text {high }} \mathrm{CD} 8(\%)$ & 50.62 & 41.16 & 0.108 & 32.84 & 41.12 & 0.100 & 44.04 & 26.32 & 0.076 \\
\hline $\mathrm{CD} 3 \mathrm{e}^{+} \mathrm{CD} 44^{\text {high }} \mathrm{CD} 62 \mathrm{~L}^{\text {lo }} \mathrm{CD} 4(\%)$ & 61.52 & 62.15 & 0.294 & 55.59 & 44.15 & 0.121 & 63.34 & 69.52 & 0.084 \\
\hline $\mathrm{CD} \mathrm{e}^{+} \mathrm{CD} 44_{\text {high }} \mathrm{CD} 62 \mathrm{~L}^{\text {lo }} \mathrm{CD} 8(\%)$ & 43.66 & 49.65 & 0.200 & 59.09 & 53.59 & 0.208 & 45.22 & 68.55 & 0.046 \\
\hline $\mathrm{CD} 3 \mathrm{e}^{+} \mathrm{CD} 4{ }^{+} \mathrm{CD} 25^{\text {high }} \mathrm{CD} 127^{\text {lo }}(\%)$ & 6.90 & 8.90 & 0.302 & 7.70 & 9.90 & 0.249 & 12.80 & 10.00 & 0.470 \\
\hline $\mathrm{CD}_{11 \mathrm{~b}}{ }^{+} \mathrm{Gr}-1^{+} / \mathrm{CD} 11 \mathrm{~b}^{+}(\%)$ & 27.16 & 15.03 & 0.001 & 32.11 & 18.81 & 0.195 & 12.69 & 8.68 & 0.100 \\
\hline
\end{tabular}

Data of median ( $\mathrm{n}=8$ mice per group). Bold represents significant difference.

Table II. Subsets of cells in peritoneal lavage fluid under the tumor-bearing state.

\begin{tabular}{|c|c|c|c|c|c|c|c|c|c|}
\hline & \multicolumn{3}{|c|}{ Day 7} & \multicolumn{3}{|c|}{ Day 14} & \multicolumn{3}{|c|}{ Day 21} \\
\hline & \multicolumn{3}{|c|}{ Metformin } & \multicolumn{3}{|c|}{ Metformin } & \multicolumn{3}{|c|}{ Metformin } \\
\hline & - & + & $p$-Value & - & + & $p$-Value & - & + & $p$-Value \\
\hline CD8/CD4 (ratio) & 0.43 & 0.58 & 0.184 & 0.31 & 0.45 & 0.830 & 0.45 & 0.51 & 0.848 \\
\hline CD3e-NK1.1+ $(\%)$ & 7.88 & 7.36 & 0.956 & 4.63 & 2.08 & 0.777 & 6.04 & 5.64 & 0.552 \\
\hline $\mathrm{CD} 3 \mathrm{e}^{+} \mathrm{NK} 1.1^{+} \mathrm{CD} 8 \mathrm{a}^{+}(\%)$ & 0.19 & 0.12 & 0.374 & 1.23 & 2.01 & 0.486 & 0.23 & 0.39 & 0.401 \\
\hline $\mathrm{CD} 3 \mathrm{e}^{+} \mathrm{CD} 44^{\mathrm{lo}} \mathrm{CD} 62 \mathrm{~L}^{\text {high }} \mathrm{CD} 4(\%)$ & 7.91 & 8.86 & 0.280 & 7.71 & 6.06 & 0.444 & 20.19 & 13.50 & 0.140 \\
\hline $\mathrm{CD} 3 \mathrm{e}^{+} \mathrm{CD} 44^{\mathrm{lo}} \mathrm{CD} 62 \mathrm{~L}^{\text {high }} \mathrm{CD} 8(\%)$ & 18.21 & 20.68 & 0.243 & 19.23 & 17.82 & 0.296 & 34.45 & 35.32 & 0.252 \\
\hline $\mathrm{CD} 3 \mathrm{e}^{+} \mathrm{CD} 44^{\text {high }}{ }^{2}$ 62L ${ }^{\text {high }} \mathrm{CD} 4(\%)$ & 78.75 & 74.99 & 0.160 & 78.58 & 84.27 & 0.357 & 55.11 & 63.59 & 0.120 \\
\hline $\mathrm{CD} \mathrm{e}^{+} \mathrm{CD} 44^{\text {high }} \mathrm{CD} 62 \mathrm{~L}^{\text {high }} \mathrm{CD} 8(\%)$ & 73.06 & 72.74 & 0.475 & 74.94 & 77.00 & 0.470 & 50.37 & 57.66 & 0.167 \\
\hline $\mathrm{CD} 3 \mathrm{e}^{+} \mathrm{CD} 44$ high $\mathrm{CD} 62 \mathrm{~L}^{\text {lo }} \mathrm{CD} 4(\%)$ & 12.43 & 15.41 & 0.106 & 13.64 & 9.66 & 0.196 & 21.35 & 21.25 & 0.291 \\
\hline $\mathrm{CD} \mathrm{e}^{+} \mathrm{CD} 44^{\text {high }} \mathrm{CD} 62 \mathrm{~L}^{\text {lo }} \mathrm{CD} 8(\%)$ & 7.49 & 6.67 & 0.140 & 9.01 & 5.50 & 0.091 & 11.25 & 5.20 & 0.025 \\
\hline $\mathrm{CD} 3 \mathrm{e}^{+} \mathrm{CD} 4{ }^{+} \mathrm{CD} 25^{\text {high }} \mathrm{CD} 127^{\text {lo }}(\%)$ & 11.60 & 10.20 & 0.293 & 10.20 & 8.10 & 0.501 & 10.80 & 11.40 & 0.516 \\
\hline $\mathrm{CD}_{11} \mathrm{~b}^{+} \mathrm{Gr}-1^{+} / \mathrm{CD} 11 \mathrm{~b}^{+}(\%)$ & 32.35 & 12.66 & 0.018 & 23.23 & 6.33 & 0.026 & 37.63 & 10.00 & 0.029 \\
\hline
\end{tabular}

Data of median ( $\mathrm{n}=8$ mice per group). Bold represents significant difference.

In conclusion, we demonstrated that metformin induces protection against peritoneal tumor dissemination by preventing mobilization of MDSCs to the tumor site and immune exhaustion, thus conserving the ability of IFN- $\gamma$ production in T-cells from the tumor microenvironment. These findings could broaden our understanding of metformin action on intraperitoneal tumors and on immune-suppressive cells and contribute to the development of new immunotherapies against peritoneal dissemination.

\section{Conflicts of Interest}

The Authors have no conflicts of interest regarding this study.

\section{Authors' Contributions}

T. Hirayama designed, performed the experiments and wrote the paper. Y. Nagata oversaw the study design and data interpretation. M. Nishida performed the experiments. M. Matsuo, S. Kobayashi, A. Yoneda, K. Kanetaka, and H. Udono contributed to extensive discussions and critical manuscript reading. S. Eguchi supervised the project, designed the experiments and wrote the paper.

\section{References}

1 Morano WF, Aggarwal A, Love P, Richard SD, Esquivel J and Bowne WB: Intraperitoneal immunotherapy: Historical perspectives and modern therapy. Cancer Gene Ther 23(11): 373-381, 2016. PMID: 27834358. DOI: 10.1038/cgt.2016.49 
A

\section{Tregs}

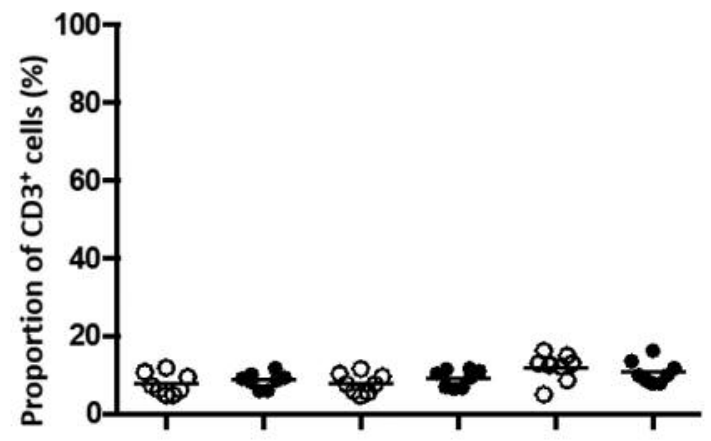

Metformin

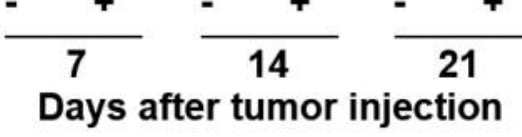

B

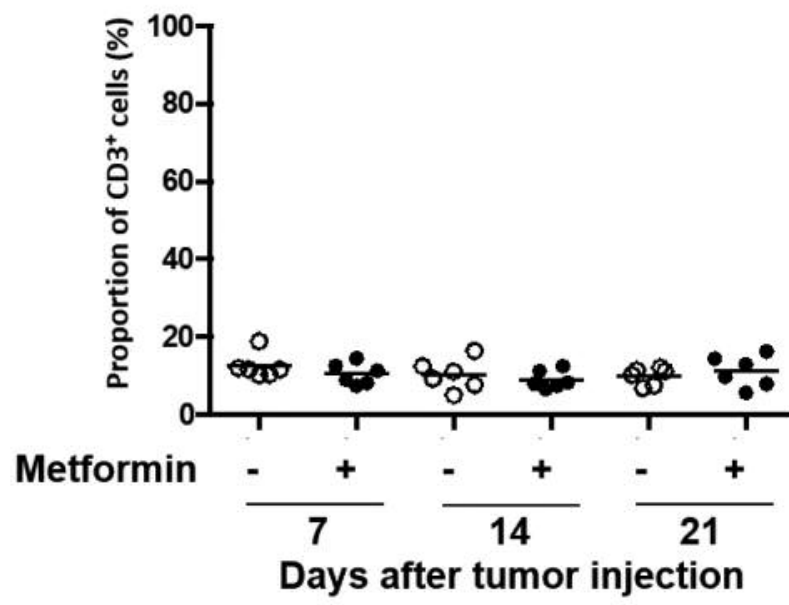

MDSCs

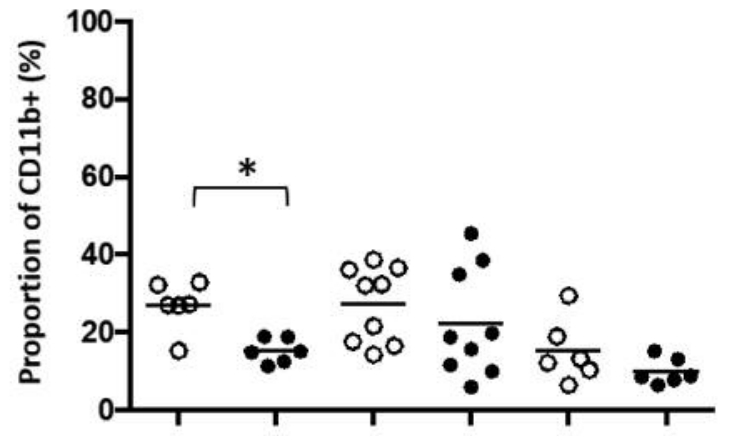

Metformin
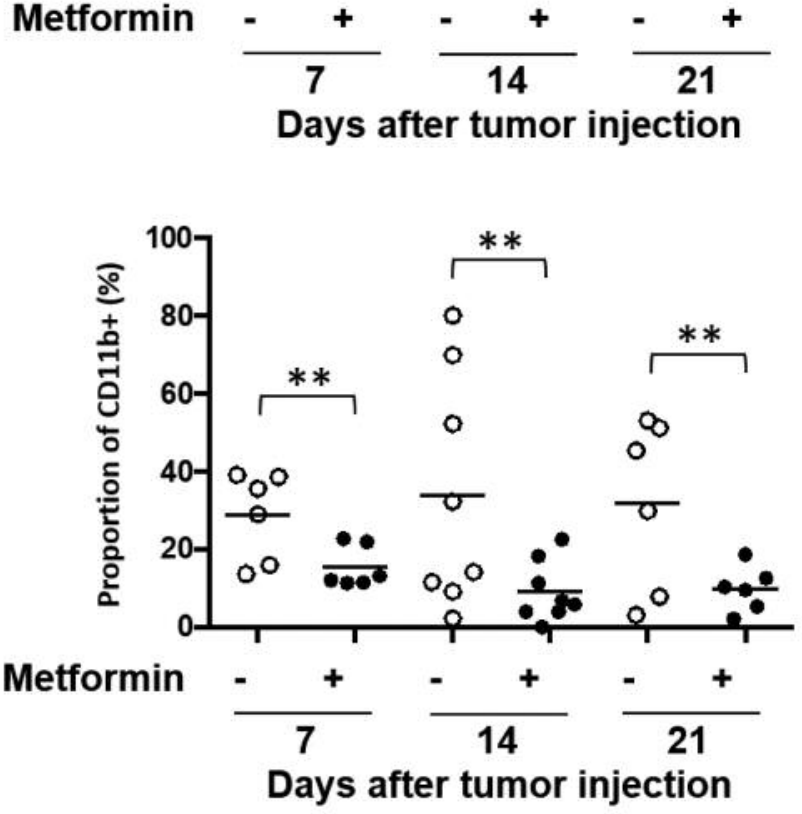

Figure 8. Continued
2 Yoneda A, Ito S, Susumu S, Matsuo M, Taniguchi K, Tajima Y, Eguchi S, Kanematsu T and Nagata Y: Immunological milieu in the peritoneal cavity at laparotomy for gastric cancer. World $\mathrm{J}$ Gastroenterol 18(13): 1470-1478, 2012. PMID: 22509078. DOI: 10.3748/wjg.v18.i13.1470

3 Dunn GP, Bruce AT, Ikeda H, Old LJ and Schreiber RD: Cancer immunoediting: From immunosurveillance to tumor escape. Nat Immunol 3(11): 991-998, 2002. PMID: 12407406. DOI: 10. 1038/ni1102-991

4 Scharping NE, Menk AV, Whetstone RD, Zeng X and Delgoffe GM: Efficacy of PD-1 blockade is potentiated by metformininduced reduction of tumor hypoxia. Cancer Immunol Res 5(1): 9-16, 2017. PMID: 27941003. DOI: 10.1158/2326-6066.CIR-160103

5 Eikawa S, Nishida M, Mizukami S, Yamazaki C, Nakayama E and Udono H: Immune-mediated antitumor effect by type 2 diabetes drug, metformin. Proc Natl Acad Sci USA 112(6): 1809-1814, 2015. PMID: 25624476. DOI: 10.1073/pnas.1417636112
6 Lee MS, Hsu CC, Wahlqvist ML, Tsai HN, Chang YH and Huang YC: Type 2 diabetes increases and metformin reduces total, colorectal, liver and pancreatic cancer incidences in taiwanese: A representative population prospective cohort study of 800,000 individuals. BMC Cancer 11: 20, 2011. PMID: 21241523. DOI: $10.1186 / 1471-2407-11-20$

7 Kim YI, Kim SY, Cho SJ, Park JH, Choi IJ, Lee YJ, Lee EK, Kook MC, Kim CG, Ryu KW and Kim YW: Long-term metformin use reduces gastric cancer risk in type 2 diabetics without insulin treatment: A nationwide cohort study. Aliment Pharmacol Ther 39(8): 854-863, 2014. PMID: 24612291. DOI: 10.1111/apt.12660

8 Quinn BJ, Kitagawa H, Memmott RM, Gills JJ and Dennis PA: Repositioning metformin for cancer prevention and treatment. Trends Endocrinol Metab 24(9): 469-480, 2013. PMID: 2377 3243. DOI: $10.1016 /$ j.tem.2013.05.004

9 Daugan M, Dufay Wojcicki A, d'Hayer B and Boudy V: Metformin: An anti-diabetic drug to fight cancer. Pharmacol Res 113(Pt A): 675685, 2016. PMID: 27720766. DOI: 10.1016/ j.phrs.2016.10.006 

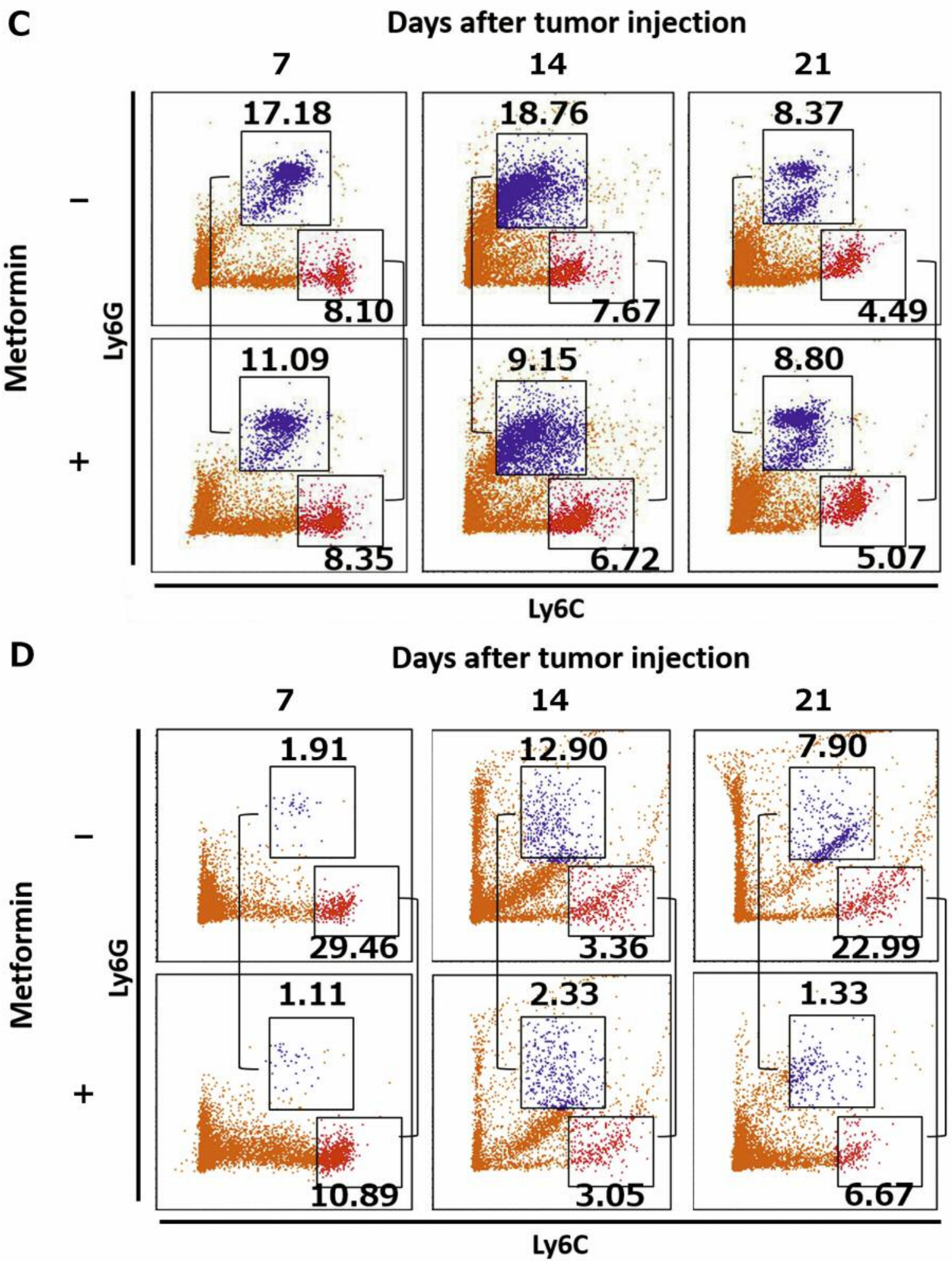

Figure 8. Myeloid-derived suppressor cells (MDSCs) induction regulated by metformin. Cells from the spleen (A) and peritoneal lavage fluid (B) from tumor-injected mice treated with (+) or without (-) metformin were isolated on day 7, 14, and 21. Induction of polymorphonuclear MDSCs (PMNMDSCs) was inhibited in the spleen of metformin-treated mice, monocytic MDSCs (M-MDSCs) were also inhibited in the peritoneal cavity. The results are summarized in Tables I and II. In A, the y-axis represents the proportion of $C D 3^{+} C D 4^{+} C D 25^{\text {high }} \mathrm{CD} 127$ low cells in $\mathrm{CD} 3^{+}$cells; in $\mathrm{B}$, it represents the proportion of $C D 11 b^{+} L y 6 G^{+} / L y 6 C^{\text {high }}$ cells in $C D 11 b^{+}$cells. $n=6$ per group. The horizontal bars indicate the median value. Significantly different at $* p<0.01$ and $* * p<0.05$. C, D: Population of MDSCs in cells collected from the spleen $(C)$ and in peritoneal lavage fluid $(D)$. 

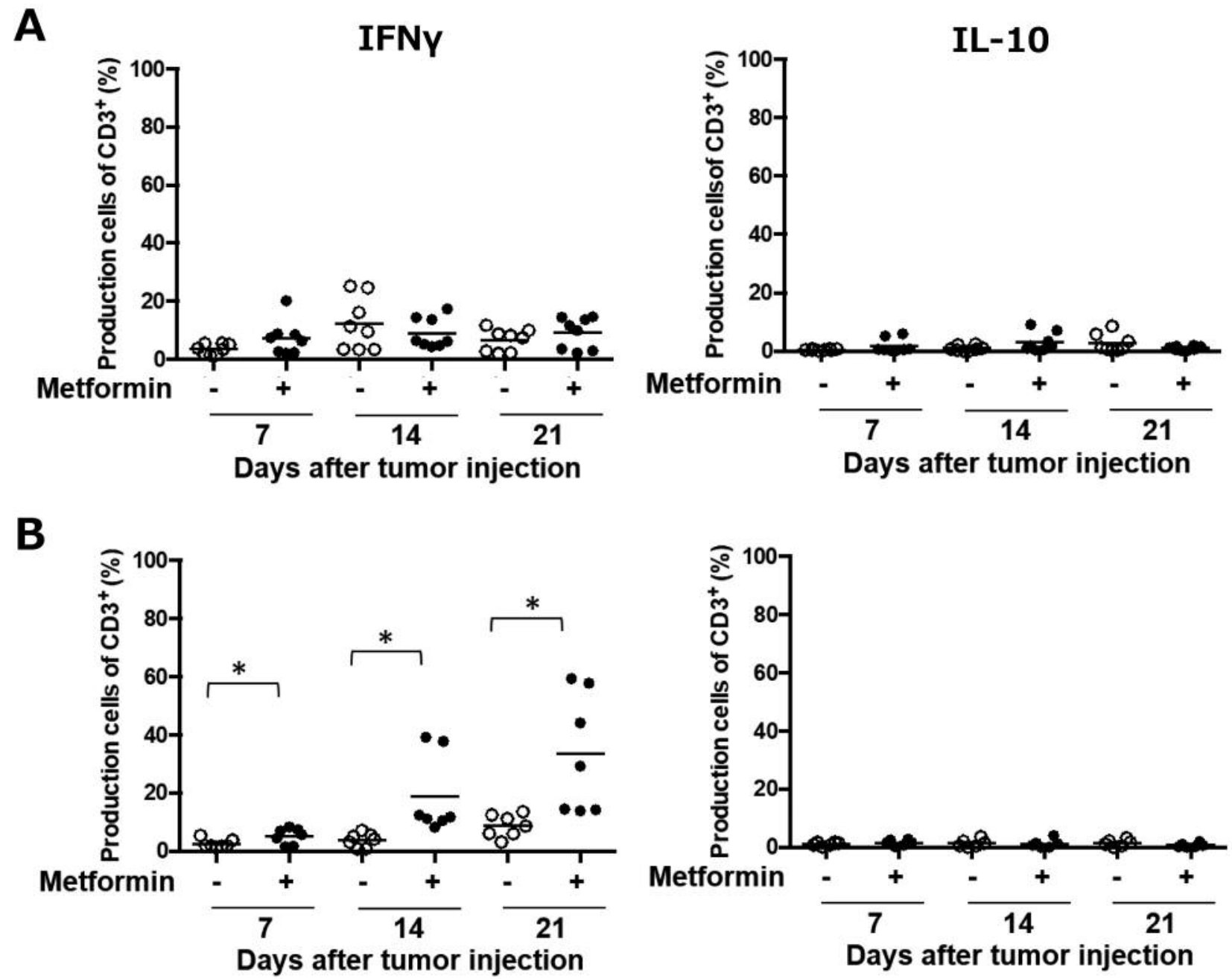

Figure 9. Cytokine production by T-cells in tumor-injected mice, measured by intracellular cytokine staining. Cells collected from the spleen (A) and peritoneal lavage fluid $(B)$ on day 7,14 , and 21 were analyzed for interferon- $\gamma$ (IFN- $\gamma)$ and interleukin 10 (IL10) (n=6 per group). Intracellular cytokine staining was performed following commercial protocols described in the Materials and Methods. Results are the percentage of cytokineproducing $\mathrm{CD}^{+}$cells. The horizontal bars indicate the median value. *Significantly different at $p<0.05$.

10 Kato K, Gong J, Iwama H, Kitanaka A, Tani J, Miyoshi H, Nomura K, Mimura S, Kobayashi M, Aritomo Y, Kobara H, Mori H, Himoto T, Okano K, Suzuki Y, Murao K and Masaki T: The antidiabetic drug metformin inhibits gastric cancer cell proliferation in vitro and in vivo. Mol Cancer Ther 11(3): 549560, 2012. PMID: 22222629. DOI: 10.1158/1535-7163.MCT11-0594

11 Li L, Wang L, Li J, Fan Z, Yang L, Zhang Z, Zhang C, Yue D, Qin G, Zhang T, Li F, Chen X, Ping Y, Wang D, Gao Q, He Q, Huang L, Li H, Huang J, Zhao X, Xue W, Sun Z, Lu J, Yu JJ, Zhao J, Zhang B and Zhang Y: Metformin-induced reduction of CD39 and CD73 blocks myeloid-derived suppressor cell activity in patients with ovarian cancer. Cancer Res 78(7): 1779-1791, 2018. PMID: 29374065. DOI: 10.1158/0008-5472.CAN-17-2460

12 Law concerning the protection and control of animals (law no. 105, October 1, 1973). Jikken Dobutsu 31(3): 221-231, 1982. PMID: 7140834.
13 A 1990 report on the actual state of the care and management of experimental animals in Japan. JALAS Subcommittee on Standards Relating to the Care and Management, etc. of Experimental Animals. Jikken Dobutsu 41(3): 395-400, 1992. PMID: 1505634.

14 National Research Council (US) Committee for the Update of the Guide for the Care and Use of Laboratory Animals. 8th edition. Washington (DC): National Academies Press (US), 2011. PMID: 21595115. DOI: $10.17226 / 12910$

15 Sendo F, Aoki T, Boyse EA and Buafo CK: Natural occurrence of lymphocytes showing cytotoxic activity to balb/c radiationinduced leukemia RL male 1 cells. J Natl Cancer Inst 55(3): 603-609, 1975. PMID: 1159837. DOI: 10.1093/jnci/55.3.603

16 Sato H, Boyse EA, Aoki T, Iritani C and Old LJ: Leukemiaassociated transplantation antigens related to murine leukemia virus. The X.1 system: Immune response controlled by a locus linked to H-2. J Exp Med 138(3): 593-606, 1973. PMID: 4727915. DOI: $10.1084 /$ jem.138.3.593 
17 Strober W: Trypan blue exclusion test of cell viability. Curr Protoc Immunol 111: A3.B.1-3, 2015. PMID: 26529666. DOI: 10.1002/0471142735.ima03bs111

18 Kasagi Y, Harada Y, Morodomi Y, Iwai T, Saito S, Yoshida K, Oki E, Saeki H, Ohgaki K, Sugiyama M, Onimaru M, Maehara $\mathrm{Y}$ and Yonemitsu Y: Peritoneal dissemination requires an SP1dependent CXCR4/CXCL12 signaling axis and extracellular matrix-directed spheroid formation. Cancer Res 76(2): 347-357, 2016. PMID: 26744523. DOI: 10.1158/0008-5472.CAN-15-1563

19 Besmer DM, Curry JM, Roy LD, Tinder TL, Sahraei M, Schettini J, Hwang SI, Lee YY, Gendler SJ and Mukherjee P: Pancreatic ductal adenocarcinoma mice lacking mucin 1 have a profound defect in tumor growth and metastasis. Cancer Res 71(13): 4432-4442, 2011. PMID: 21558393. DOI: 10.1158/00085472.CAN-10-4439

20 Bottsford-Miller J, Choi HJ, Dalton HJ, Stone RL, Cho MS, Haemmerle M, Nick AM, Pradeep S, Zand B, Previs RA, Pecot CV, Crane EK, Hu W, Lutgendorf SK, Afshar-Kharghan V and Sood AK: Differential platelet levels affect response to taxanebased therapy in ovarian cancer. Clin Cancer Res 21(3): 602-610, 2015. PMID: 25473001. DOI: 10.1158/1078-0432.CCR-14-0870

21 Parker KH, Beury DW and Ostrand-Rosenberg S: Myeloid-derived suppressor cells: Critical cells driving immune suppression in the tumor microenvironment. Adv Cancer Res 128: 95-139, 2015. PMID: 26216631. DOI: 10.1016/bs.acr.2015. 04.002

22 Tsai BY, Suen JL and Chiang BL: Lentiviral-mediated foxp3 rnai suppresses tumor growth of regulatory T-cell-like leukemia in a murine tumor model. Gene Ther 17(8): 972-979, 2010. PMID: 20357829. DOI: $10.1038 /$ gt 2010.38

23 Hirsch HA, Iliopoulos D, Tsichlis PN and Struhl K: Metformin selectively targets cancer stem cells, and acts together with chemotherapy to block tumor growth and prolong remission. Cancer Res 69(19): 7507-7511, 2009. PMID: 19752085. DOI: 10.1158/0008-5472.CAN-09-2994

24 Kunisada Y, Eikawa S, Tomonobu N, Domae S, Uehara T, Hori S, Furusawa Y, Hase K, Sasaki A and Udono H: Attenuation of $\mathrm{CD} 4(+) \mathrm{CD} 25(+)$ regulatory t cells in the tumor microenvironment by metformin, a type 2 diabetes drug. EBioMedicine 25: 154-164, 2017. PMID: 29066174. DOI: 10.1016/j.ebiom.2017.10.009

25 Kim SH, Li M, Trousil S, Zhang Y, Pasca di Magliano M, Swanson KD and Zheng B: Phenformin inhibits myeloid-derived suppressor cells and enhances the anti-tumor activity of PD-1 blockade in melanoma. J Invest Dermatol 137(8): 1740-1748, 2017. PMID: 28433543. DOI: 10.1016/j.jid.2017.03.033

26 Marvel D and Gabrilovich DI: Myeloid-derived suppressor cells in the tumor microenvironment: Expect the unexpected. J Clin Invest 125(9): 3356-3364, 2015. PMID: 26168215. DOI: 10.11 72/JCI80005
27 Obermajer N, Muthuswamy R, Lesnock J, Edwards RP and Kalinski P: Positive feedback between PGE2 and COX2 redirects the differentiation of human dendritic cells toward stable myeloidderived suppressor cells. Blood 118(20): 5498-505, 2011. PMID: 21972293. DOI: 10.1182/blood-2011-07-365825

28 Huang B, Pan PY, Li Q, Sato AI, Levy DE, Bromberg J, Divino CM and Chen SH: Gr-1+CD115+ immature myeloid suppressor cells mediate the development of tumor-induced T-regulatory cells and Tcell anergy in tumor-bearing host. Cancer Res 66(2): 1123-1131, 2006. PMID: 16424049. DOI: 10.1158/0008-5472.CAN-05-1299

29 Serafini P, Mgebroff S, Noonan K and Borrello I: Myeloidderived suppressor cells promote cross-tolerance in B-cell lymphoma by expanding regulatory T-cells. Cancer Res 68(13): 5439-5449, 2008. PMID: 18593947. DOI: 10.1158/00085472.CAN-07-6621

30 Yang R, Cai Z, Zhang Y, Yutzy WHt, Roby KF and Roden RB: Cd80 in immune suppression by mouse ovarian carcinomaassociated Gr-1+CD11b+ myeloid cells. Cancer Res 66(13): 6807-6815, 2006. PMID: 16818658. DOI: 10.1158/00085472.CAN-05-3755

31 Isaza-Restrepo A, Martin-Saavedra JS, Velez-Leal JL, VargasBarato F and Riveros-Duenas R: The peritoneum: Beyond the tissue - a review. Front Physiol 9: 738, 2018. PMID: 29962968. DOI: $10.3389 /$ fphys.2018.00738

32 Shin HS, Ko J, Kim DA, Ryu ES, Ryu HM, Park SH, Kim YL, Oh ES and Kang DH: Metformin ameliorates the phenotype transition of peritoneal mesothelial cells and peritoneal fibrosis via a modulation of oxidative stress. Sci Rep 7(1): 5690, 2017. PMID: 28720775. DOI: 10.1038/s41598-017-05836-6

$33 \mathrm{Hu} \mathrm{Z}, \mathrm{Hu} \mathrm{S}, \mathrm{Wu} \mathrm{Y,} \mathrm{Li} \mathrm{S,} \mathrm{He} \mathrm{C,} \mathrm{Xing} \mathrm{X,} \mathrm{Wang} \mathrm{Y} \mathrm{and} \mathrm{Du} \mathrm{X:}$ Accumulation and suppressive function of regulatory T-cells in malignant ascites: Reducing their suppressive function using arsenic trioxide in vitro. Oncol Lett 15(4): 5384-5390, 2018. PMID: 29552182. DOI: 10.3892/ol.2018.7974

34 Choi HS, Ha SY, Kim HM, Ahn SM, Kang MS, Kim KM, Choi MG, Lee JH, Sohn TS, Bae JM, Kim S and Kang ES: The prognostic effects of tumor infiltrating regulatory T-cells and myeloid derived suppressor cells assessed by multicolor flow cytometry in gastric cancer patients. Oncotarget 7(7): 79407951, 2016. PMID: 26799288. DOI: 10.18632/oncotarget.6958

Received July 3, 2019

Revised July 17, 2019

Accepted July 19, 2019 